\title{
Promoting Respectful Maternity Care Resource Package-Implementing respectful maternity care in Kenya
}

Population Council

Follow this and additional works at: https://knowledgecommons.popcouncil.org/departments_sbsr-rh

Part of the Community Health and Preventive Medicine Commons, Demography, Population, and Ecology Commons, Family, Life Course, and Society Commons, International Public Health Commons, Maternal and Child Health Commons, and the Women's Health Commons How does access to this work benefit you? Let us know!

\section{Recommended Citation}

"Promoting Respectful Maternity Care Resource Package-Implementing respectful maternity care in Kenya," brief. Washington, DC and Nairobi: Population Council, 2015. 
The Respectful Maternity Care Resource Package was developed by the Heshima project as part of the USAID Translating Research into Action (TRAction) project.

\section{WHY USE RMC RESOURCE PACKAGE?}

The resource package is designed to be used by program managers, supervisors, trainers, technical advisors, and others who organize or facilitate RMC training workshops for sexual and reproductive health as well as skills updates in emergency obstetric and newborn care training. The RMC Resource Package provides experienced facilitators with the background information, materials, instructions, and tips for promoting respectful care in reproductive, maternal, and newborn health services in both facilities and communities.

The Resource Package advances a specific agenda: promoting increased support, advocacy, and provision of high quality, woman-centered maternity care. Effects are unlikely immediately after one workshop; they may be incremental. It takes a "hands-on" approach to empower service providers, communities, and policymakers with the knowledge and skills for tackling disrespect and abuse during childbirth.

\begin{abstract}
"Our involvement was training and ensuring the midwives and the community health workers within our sub-county adhered to what the heshima project was advocating for...on safe motherhood and rights; the client's rights and also the provider's rights. We also trained the community, not just the community health workers, but the community itself."
\end{abstract}

-REPRODUCTIVE HEALTH COORDINATOR, DISTRICT HOSPITAL

This intervention is part of the respectful maternity care (RMC) Resource Package developed by the partners of the Kenya Heshima Project and focuses on policy, health system and community levels. The package includes the most effective interventions, and provides practical, low cost, and easily adaptable strategies for facilities and communities to reduce disrespectful and abusive treatment during childbirth. RMC refers to the humane and dignified treatment of a childbearing woman throughout her pregnancy, birth, and the postnatal period.
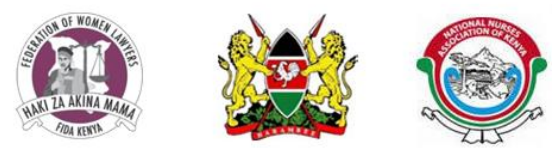


\section{CORE INTERVENTION ELEMENTS}

\section{HEALTH SYSTEM}

The core intervention element at the system level is a one day orientation workshop for district reproductive health stakeholders and facility managers sensitizing them on the issue of D\&A during childbirth and for implementation of the RMC Resource Package.

\section{FACILITY}

At the facility level, a three day RMC training for service providers focuses on transformative practice, accountability, ethics, and values clarification and attitude transformation (VCAT) creating opportunities for each facility team to identify drivers of D\&A they wish to address.

During the Heshima project each facility was supported in identifying mechanisms for sustaining positive attitude changes as well as including counseling, mentoring, and maternity open days. The training also provided methods for critical self-evaluation of individual behaviors and attitudes that might contribute to D\&A. Introspective assessment of individual providers and investment in the intervention affected the training implementation and its effect.

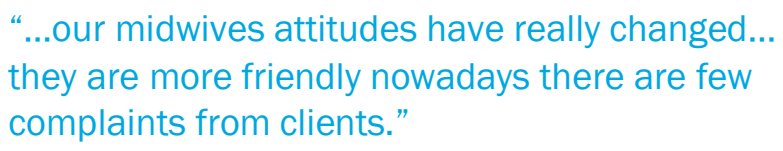

\section{-NURSE MANAGER, GOVERNMENT FACILITY}

Administration of pre- and post tests measured improved staff attitudes, morale, and communication. Around $80 \%$ of providers in each study maternity unit were trained and provided individualized work plans to deal with D\&A drivers at the facility level.

These trainings promoted teamwork to enrich discussions of key D\&A issues and improve managers' and providers' team and individual accountability. One facility adopted international organizational standards and other facilities adopted performance contracts.

\section{COMIMUNITY}

Implementation of Heshima interventions within communities varied by engagement and execution.
Community dialogue days began with an introduction by Community Health Workers (CHWs) or the leading Community Health Extension Worker (CHEW) from a particular facility site or catchment area, followed by a consortium partner and a local trainer leading a discussion about treatment typically experienced during childbirth.

$$
\begin{aligned}
& \text { "There are a lot of lessons like } \\
& \text { communication...it is now at all levels where you } \\
& \text { are communicating horizontally, downward and } \\
& \text { even to your seniors during advocacy." } \\
& \text {-COMMUNITY HEALTH WORKER }
\end{aligned}
$$

Community education workshops on health rights, particularly related to RMC, allowed participants an opportunity to ask questions to ensure their comprehension. Community members were left with information on RMC, the legal mechanisms available, and how to report occurrences. These workshops emphasized male involvement, men comprising part of the trainer population also actively educating and empowering communities, as well as constituting a participant population demanding RMC as a right and seeking redress for D\&A.

"Right now they have really changed... before you
culd call for help because you have maybe given
birth before your expected hour and no of them
would come."

\section{ITERATIVE DEVELOPMENT}

Monitoring of the intervention in facilities and communities by Heshima and county and facility management teams revealed different challenges and facility needs over the course of the implementation, which allowed for training package refinement over time. During the first workshop, Heshima realized that providers lacked knowledge of professional ethics and regulatory standards of care, and decided to include sessions on these issues in subsequent RMC workshops.

The RMC Resource Package can be used in any health care setting but should be reviewed and adapted for the local, or county context.

\section{For more information, please contact:}

Population Council

4301 Connecticut Avenue NW, Suite 280

Washington DC 20008

USA

cwarren@popcouncil.org
Population Council

General Accident Insurance House

Ralph Bunche Road, PO Box 17643 - 00500

Nairobi, Kenya

cndwiga@popcouncil.org

Translating Research into Action, TRAction, is funded by United States Agency for International Development (USAID) under Cooperative Agreement No. GHS-A-00-09-00015-00. This document is made possible by the support of the American People through the Unites States Agency for International Development (USAID). The contents of this report are the sole responsibility of the Population Council and do not necessarily reflect the views of USAID or the United States government.

The Population Council conducts research and delivers solutions that improve lives around the world. Big ideas supported by evidence: It's our model for global change. www.popcouncil.org

(C) 2015 The Population Council, Inc. 